\title{
Mariola Piłatowska
}

\author{
SYLWETKA NAUKOWA \\ PROFESORA ZYGMUNTA ZIELIŃSKIEGO (1929-2009)
}

Profesor Zygmunt Zieliński urodził się 7 kwietnia 1929 roku w Strzelnie. W 1950 roku rozpoczął studia w Wyższej Szkole Ekonomicznej w Szczecinie, którą włączono w 1955 roku do nowo utworzonej Politechniki Szczecińskiej. Studia pierwszego stopnia Profesor ukończył w 1954 roku, a studia drugiego stopnia (magisterskie) - w 1955 roku. W marcu 1963 roku uzyskał stopień doktora nauk ekonomicznych na Wydziale Morskim WSE w Sopocie, a 26 czerwca 1970 roku - stopień doktora habilitowanego nauk ekonomicznych na Wydziale Przemysłu Wyższej Szkoły Ekonomicznej w Katowicach. Tytuł naukowy profesora nadzwyczajnego uzyskał w styczniu 1977 roku, a profesora zwyczajnego 16 grudnia 1988 roku.

Działalność naukowo-dydaktyczną Profesora Zielińskiego można podzielić na dwa okresy, tj. okres szczeciński (lata 1952-1980) i okres toruński (lata 1981-2009).

Pracę naukowo-dydaktyczną Profesor podjął 1 września 1952 roku w Katedrze Statystyki Wyższej Szkoły Ekonomicznej, a następnie Politechniki Szczecińskiej. I to właśnie Politechnika Szczecińska na wiele lat stała się uczelnią, z która związany był Zygmunt Zieliński. Tu w 1955 roku został powołany na stanowisko starszego asystenta, w roku 1963 - adiunkta, w czerwcu 1968 roku - docenta, a po otrzymaniu tytułu naukowego profesora nadzwyczajnego został zatrudniony na stanowisku profesora nadzwyczajnego (w styczniu 1977 roku).

Po ukończeniu studiów magisterskich, w latach 1955-1957, Profesor Zieliński zajmował się problemami statystyki transportowej, a w szczególności problemami statystyki przewozów kolejowych. Od roku 1958 prowadził analizy wahań sezonowych w transporcie w Polsce. Problemami tymi zajmował się do 1965 roku. Wyniki swych badań Profesor opublikował w latach 1959-1965 
w pięciu artykułach naukowych oraz w monografii pt. Statystyczne studium sezonowości towarowych przewozów kolejami w Polsce w latach 1947-1960 (Zeszyty Naukowe Politechniki Szczecińskiej nr 59, Szczecin 1965).

W następnym okresie, tzn. od 1965 roku, Profesor Zieliński zajmował się metodami analizy wahań sezonowych. Były to badania typu teoretycznometodologicznego; ich wyniki Profesor przedstawił w pięciu artykułach naukowych oraz w rozprawie habilitacyjnej pt. Ekonometryczne metody analizy wahań sezonowych (Zeszyty Naukowe Politechniki Szczecińskiej nr 112, Szczecin 1969).

Od roku 1969 Profesor zajmował się problemami zastosowań ekonometrii $\mathrm{w}$ transporcie, a w szczególności w badaniu potrzeb przewozowych. Wyniki tych prac przedstawił w sześciu artykułach naukowych oraz w publikacji pt. Wybrane zagadnienia ekonometrii i jej zastosowań do analizy przewozów (Politechnika Szczecińska, Szczecin 1978).

Od 1975 roku Profesor Zieliński zaczął zajmować się teorią dynamicznych modeli ekonometrycznych, opartą na teorii procesów stochastycznych. Pierwsze wyniki badań dotyczące tego tematu przedstawił w monografii: Metody analizy dynamiki i rytmiczności zjawisk gospodarczych (PWN, Warszawa 1979).

W okresie pracy na Politechnice Szczecińskiej Profesor prowadził wykłady i ćwiczenia z zakresu statystyki teoretycznej, rachunku prawdopodobieństwa, statystyki matematycznej, matematyki dla ekonomistów, statystyki ekonomicznej i transportowej, ekonometrii i badań operacyjnych oraz seminaria magisterskie.

W okresie działalności naukowo-dydaktycznej na Politechnice Szczecińskiej Profesor Zieliński pełnił również wiele funkcji. W latach 1970-1981 pełnił funkcję zastępcy dyrektora i dyrektora Instytutu Rachunku Ekonomicznego, a od 1976 roku - dyrektora Instytutu Nauk Ekonomiczno-Społecznych Politechniki Szczecińskiej. Równolegle pełnił funkcję kierownika Zakładu Ekonometrii i Badań Operacyjnych, który powstał z Jego inicjatywy. W latach 1972 -1975 Profesor Zieliński był Prorektorem ds. Dydaktycznych, a w latach 1975-1980 - Rektorem Politechniki Szczecińskiej i Przewodniczącym Środowiskowego Kolegium Rektorów Szkół Wyższych w Szczecinie.

Drugi okres pracy naukowo-dydaktycznej Profesora Zygmunta Zielińskiego rozpoczął się od momentu przejścia do pracy na Wydziale Nauk Ekonomicznych Uniwersytetu Mikołaja Kopernika w Toruniu, tj. od lutego 1981 roku. Odtąd też zaczął się okres toruński Jego życia.

W okresie tym głównym tematem badań Profesora Zielińskiego była teoria dynamicznych modeli ekonometrycznych i ich zastosowań. Efektem tych badań była kolejna monografia Profesora pt. Analiza spektralna w modelowaniu ekonometrycznym (PWN, Warszawa 1986, współautor: L. Talaga). Dla napisania tej monografii szczególnie przydatny był trzymiesięczny staż naukowy w Uni- 
wersytecie Stanowym w Tempe w Arizonie, który Profesor odbył na przełomie 1981 i 1982 roku.

W latach 1986-1990 Profesor Zieliński podjął się, wraz z zespołem pracowników kierowanej przez siebie Katedry Ekonometrii i Statystyki UMK, realizacji tematu badawczego w ramach centralnego programu badań podstawowych (CPBP 10.9.I.3) pt. „Modelowanie procesów ekonomicznych w świetle koncepcji zgodnych modeli dynamicznych". W trakcie realizacji tego tematu Profesor podsuwał nowe tematy badawcze, zachęcał do wysiłku, inspirując tym samym młodych pracowników naukowych do podejmowania odważnych tematów. Efektem tego było opublikowanie wielu artykułów naukowych, opracowanie kilku prac doktorskich i habilitacyjnych dotyczących nurtu dynamicznego modelowania ekonometrycznego. Należy tutaj dodać, że badania te nadal są kontynuowane przez Jego uczniów. Podsumowaniem badan Profesora nad budowa, analizą i weryfikacją zgodnych, dynamicznych modeli ekonometrycznych była monografia pt. Liniowe modele ekonometryczne jako narzędzie opisu $i$ analizy przyczynowych zależności zjawisk ekonomicznych (Wydawnictwo UMK, Toruń 1991).

Profesor Zygmunt Zieliński był pomysłodawcą organizowania przez Katedrę Ekonometrii i Statystyki WNEiZ UMK w Toruniu Ogólnopolskiego Seminarium Naukowego pt. Dynamiczne modele ekonometryczne. Seminaria te sa organizowane od 1989 roku w cyklu dwuletnim i stanowią doskonałe forum do prezentowania osiagnięć w dziedzinie modelowania dynamicznego ekonomicznych procesów stochastycznych zarówno dla ośrodka toruńskiego, jak i innych polskich ośrodków naukowych. Profesor Zieliński był również inicjatorem przygotowania i wydawania czasopisma w języku angielskim pt. Dynamic Econometric Models (vol. 1, 1994; vol. 2, 1995; vol. 3, 1998; vol. 4, 2000; vol. 5, 2002, vol. 6, 2004; vol. 7, 2006; vol. 8, 2008), który jest „wizytówką” tematyki prezentowanej na konferencji. Profesor był jednocześnie redaktorem naukowym tego zeszytu.

W okresie pracy na Uniwersytecie Mikołaja Kopernika w Toruniu Profesor Zieliński wykładał ekonometrię oraz badania operacyjne, a także prowadził seminaria magisterskie. W latach 1984-1985 Profesor pracowal dodatkowo w Wyższej Szkole Pedagogicznej w Szczecinie, a w latach 1985-1988 - na Uniwersytecie Szczecińskim, wykładając statystykę dla pedagogów i prawników. Od 1998 roku pracował na stanowisku profesora w Wyższej Szkole Informatyki i Ekonomii Towarzystwa Wiedzy Powszechnej w Olsztynie, gdzie wykładał ekonometrię i prowadził seminaria dyplomowe. Należy przy tym wspomnieć, że Profesor Zieliński przez cały okres pracy na Wydziale Nauk Ekonomicznych i Zarządzania UMK w Toruniu mieszkał w Szczecinie, a do pracy dojeżdżał... 350 kilometrów. Stał się przez to, jak sam mówił, człowiekiem XXI wieku, czyli „człowiekiem podróżującym”.

W okresie pracy naukowo-dydaktycznej na Wydziale Nauk Ekonomicznych i Zarządzania UMK w Toruniu Profesor Zieliński także pełnił różne funkcje. 
W latach 1981-1987 był dziekanem Wydziału Nauk Ekonomicznych UMK, w latach 1981-1990 - członkiem Senatu UMK, a w latach 1983-1999 - kierownikiem Katedry Ekonometrii i Statystyki WNEiZ UMK.

Dorobek naukowy Profesora Zygmunta Zielińskiego obejmuje ponad 100 prac naukowych, w tym 5 monografii książkowych. Omawiając poglądy naukowe i osiagnięcia Profesora należy przede wszystkim wskazać na dwie dziedziny, w których Jego wysiłki przyniosły największe owoce, tzn. na metody analizy wahan sezonowych i na teorię dynamicznych modeli ekonometrycznych opartą na teorii procesów stochastycznych.

Pierwszą pracą dotyczącą metod analizy wahań sezonowych była wspomniana już monografia Statystyczne studium sezonowości towarowych przewozów kolejami w Polsce w latach 1947-1960 (Zeszyty Naukowe Politechniki Szczecińskiej, Prace Monograficzne nr 22, Szczecin 1965). Zasadniczym celem pracy było wyjaśnienie mechanizmu powodującego wahania sezonowe w przewozach kolejowych oraz rozpoznanie tendencji do zmian w kształtowaniu się wahań. Niezależnie od wyjaśnienia tego mechanizmu, badania te wniosły wkład w rozwój metod badania sezonowości procesów gospodarczych. Wkład ten polega na adaptacji uproszczonej metody dwóch punktów do badań sezonowości, na zbadaniu statystycznej efektywności metody stosunków do trendu jako metody badania sezonowości, opracowaniu metody analizy struktury wahań sezonowych oraz metody badania zmian w sezonowości.

Kolejną książką, traktującą o metodach analizy wahań sezonowych, była praca habilitacyjna Ekonometryczne metody analizy wahań sezonowych (Zeszyty Naukowe Politechniki Szczecińskiej, Prace Monograficzne nr 55, Szczecin 1969). Myślą przewodnią tych badań była teza, że najważniejsze metody analizy wahań sezonowych można sprowadzić do ekonometrycznych równań opisowych, których parametry są sezonową, periodyczną funkcją zmiennej czasowej. Dzięki temu do analizy wahan sezonowych można stosować metody estymacji parametrów równań liniowych. Profesor Zieliński podjął się głębszej analizy przydatności tych równań w badaniach ekonometrycznych, w szczególności w składnikowej analizie ekonomicznych szeregów czasowych. Przydatność tych równań Profesor zilustrował za pomocą empirycznego modelu trendu i sezonowości harmonicznej (stałej i zmiennej) kształtowania się przewozów osób przez PKP w Polsce. Zasługuje to na uwagę z tego względu, że był to w literaturze polskiej pierwszy przykład zastosowania modelu trendu i sezonowości harmonicznej do analizy konkretnych ekonomicznych szeregów czasowych. Zastosowanie równań liniowych rzuciło nowe światło na podstawowe problemy analizy szeregów czasowych.

Pracą monograficzną Profesora Zielińskiego, która wskazała, że zastosowanie teorii procesów stochastycznych $\mathrm{w}$ analizie ekonometrycznej pozwala w istotny sposób pogłębić analizę i w nowy sposób spojrzeć na metody klasycznej ekonometrii, była książka Metody analizy dynamiki i rytmiczności zjawisk gospodarczych (PWN, Warszawa 1979). W pracy tej Profesor pokazal, że 
teoria procesów stochastycznych powinna być traktowana jako metodologiczna podstawa analizy ekonomicznych szeregów czasowych, posiadających określoną wewnętrzną strukturę. Do opisu składnikowej struktury tych procesów Profesor wykorzystał modele procesów stochastycznych: modele trendu wielomianowego o parametrach będących sezonowymi funkcjami zmiennej czasowej oraz różne modele składnika sezonowego. Profesor usystematyzował i rozwiną zagadnienia związane z estymacją składnika sezonowego na podstawie danych po eliminacji trendu oraz estymacją parametrów funkcji trendu na podstawie danych po eliminacji wahań sezonowych. Profesor badał również możliwości zastosowania filtrów liniowych do ustalania postaci analitycznej funkcji trendu, a także związki składnikowych modeli procesów stochastycznych z przyczynowo-skutkowymi modelami ekonometrycznymi. Przedstawiając postawy teorii procesów stochastycznych, analizy spektralnej i jej użyteczność w ekonometrii, Profesor wprowadził na stałe zagadnienia te do polskiej literatury ekonometrycznej.

Kolejną pracą dotyczącą zastosowania teorii procesów stochastycznych była książka Analiza spektralna w modelowaniu ekonometrycznym (PWN, Warszawa 1986, współautor: L. Talaga). Celem tej książki było przedstawienie głównych osiagnięć w zakresie zastosowań teorii procesów stochastycznych w ekonometrii. W polskiej literaturze ekonometrycznej była to pierwsza publikacja dotycząca tego zagadnienia. Przedstawione w pracy empiryczne zastosowania analizy spektralnej do wybranych procesów gospodarczych w Polsce należy uważać za przyczynek do oceny wartości poznawczej tej metody. Zastosowania te pozwalają spojrzeć w nowy sposób na problemy związane ze składnikową analizą procesów ekonomicznych oraz $\mathrm{z}$ analizą zależności między tymi procesami. W pracy tej zawarta jest, opracowana przez Profesora Zielińskiego, koncepcja budowy zgodnych liniowych modeli ekonometrycznych, którą Profesor przedstawiał już wcześniej w artykule (Zmienność w czasie..., „Przegląd Statystyczny" 1984), jak również na forum Katedry Ekonometrii i Statystyki. Istotą tej koncepcji jest uwzględnienie w trakcie specyfikacji modeli, opisujących zależności ekonomicznych procesów stochastycznych, podstawowej struktury tych procesów, tj. struktury trendowo-sezonowej i autoregresyjnej. Taka konstrukcja modelu pozwala na otrzymanie, już na etapie konstrukcji, procesu resztowego o białoszumowych własnościach, a więc najbardziej pożądanych z punktu widzenia analizy statystycznej. Koncepcja ta została rozwinięta przy założeniu, że badane procesy są stacjonarnymi procesami autoregresyjnymi, a także przy założeniu, że są one procesami niestacjonarnymi, sezonowymi, o trendach $\mathrm{w}$ wartościach średnich i stacjonarnych procesach resztowych. Analiza budowy zgodnych liniowych modeli ekonometrycznych przedstawia w nowym świetle podstawowe problemy, które zawsze pojawiały się $\mathrm{w}$ badaniach ekonometrycznych opartych na danych w postaci szeregów czasowych. Należą do nich: współliniowość związana z występowaniem trendów, eliminacja trendu i sezonowości, zastosowanie filtrów, wyznaczanie opóźnień czasowych, zwią- 
zek modeli dynamicznych dla procesów niestacjonarnych z teorią procesów stacjonarnych, właściwa interpretacja parametrów modeli ekonometrycznych, określenie udziału trendów poszczególnych procesów objaśniających w wynikowym trendzie procesu endogenicznego, zapewnienie niezależności procesów resztowych od procesów egzogenicznych. Badania empiryczne pokazały, że zgodne modele dynamiczne sa jakościowo lepsze od modeli specyfikowanych z pominięciem zasady zgodności. Świadczy to o tym, że koncepcja zgodnych liniowych modeli ekonometrycznych stanowi ważny przyczynek do teorii dynamicznych modeli ekonometrycznych.

W tym samym nurcie badań należy umieścić kolejną monografię Profesora Zielińskiego, tj. Liniowe modele ekonometryczne jako narzędzie opisu i analizy przyczynowych zależności zjawisk ekonomicznych (Wydawnictwo UMK, Toruń 1991). W pracy tej Profesor zwrócił uwagę na konieczność uwzględniania przy ocenie jakości modelu ekonometrycznego jego wartości poznawczej z punktu widzenia poznania zależności przyczynowych i przydatności do prognozowania. W związku z tym Profesor przedstawił podstawy analizy przyczynowych zależności zdarzeń zmiennych i procesów stochastycznych na tle ogólnego pojmowania przyczynowości w naukach empirycznych. Profesor wskazał, że punktem wyjścia statystyczno-empirycznej analizy zależności między ekonomicznymi procesami stochastycznymi jest badanie wewnętrznej struktury procesów-skutków i procesów-przyczyn oraz własności składnika stochastycznego i niestochastycznego. Na podstawie tych informacji można przystapić następnie do badania zależności między składnikami stochastycznymi, budując model zgodny, czy też do badania zależności między składnikami niestochastycznymi, stosując odpowiednie metody filtracji. Jego zasługą jest również dokonanie klasyfikacji modeli liniowych według ich wartości poznawczej (modele I, II, III i IV rodzaju, czy też $\alpha, \beta, \gamma$ i $\delta$ ) oddzielnie w odniesieniu do zależności między stacjonarnymi oraz niestacjonarnymi procesami ekonomicznymi. Tym samym praca ta przyczynia się do rozwoju przyczynowej teorii ekonometrii.

Wymienione prace wypełniły lukę w polskiej literaturze ekonometrycznej głównie w zakresie metod analizy wahań sezonowych, zastosowań teorii procesów stochastycznych w ekonometrii oraz opracowania koncepcji zgodnych, dynamicznych modeli ekonometrycznych.

Najnowsze publikacje Profesora dotyczyły nadal teorii modeli dynamicznych i ich zastosowań, m.in. rozszerzenia koncepcji modeli zgodnych na procesy zintegrowane $(1995,1996)$ oraz analizy porównawczej różnych koncepcji dynamicznego modelowania ekonometrycznego z punktu widzenia ich analizy poznawczej oraz prognostycznej $(2001,2002,2004,2008)$.

Do osiagnięć Profesora w zakresie dydaktycznym należy zaliczyć wypromowanie ponad 200 magistrów i 20 doktorów. Ponadto był opiekunem naukowym kilku rozpraw habilitacyjnych i wielokrotnym recenzentem rozpraw habi- 
litacyjnych, prac doktorskich i wniosków w sprawie nadania tytułu naukowego profesora.

Profesor Zygmunt Zieliński był członkiem Komitetu Statystyki i Ekonometrii PAN od 1972 roku oraz członkiem Polskiego Towarzystwa Ekonomicznego, w latach 1972-1980 był prezesem szczecińskiego oddziału TNOiK. W czasie swej długoletniej pracy Profesor otrzymał wiele nagród, m.in. osiem nagród Ministra Nauki Szkolnictwa Wyższego i Techniki, w tym sześć nagród za osiągnięcia dydaktyczne i organizacyjne oraz dwie nagrody za osiagnięcia naukowe. Otrzymał również osiem nagród Rektora Politechniki Szczecińskiej (w latach 1960-1977), w tym sześć nagród za osiagnięcia naukowe, a także dziesięć nagród Rektora Uniwersytetu Mikołaja Kopernika (w latach 1982-2001), w tym siedem nagród za działalność naukową. Profesor otrzymał również wiele odznaczeń i wyróżnień, wśród których do najważniejszych należy zaliczyć: Złoty Krzyż Zasługi (1971), Krzyż Kawalerski Orderu Odrodzenia Polski (1977), Medal Edukacji Narodowej (1978), Medal „Gryf Pomorski” (1975) oraz medale Politechniki Szczecińskiej i Uniwersytetu Mikołaja Kopernika (1996).

Profesor Zygmunt Zieliński zmarł 9 stycznia 2009 roku w Szczecinie.

Profesor Zygmunt Zieliński pracował naukowo i dydaktycznie pięćdziesiąt sześć lat, niemal do końca swojego życia. My, uczniowie Profesora, pamiętamy go jeszcze z czerwca 2008, gdy w doskonałej formie intelektualnej i fizycznej uczestniczył w kolokwium habilitacyjnym na Wydziale Nauk Ekonomicznych i Zarządzania UMK w Toruniu, a także przeprowadzał egzaminy z ekonometrii.

Przez wiele lat Profesor był kierownikiem Katedry Ekonometrii i Statystyki w Toruniu, naszym Szefem, bo tak Go nazywaliśmy. Działał z zaangażowaniem $\mathrm{w}$ interesie Katedry, ale również w interesie Wydziału. To dzięki niemu doświadczaliśmy, jak ważna jest dbałość o dobro wspólne. Profesor miał ogromny talent do całościowego i trafnego ujęcia tematu w wielu dyskusjach, przy tym wykazywał się przenikliwością i błyskotliwością w myśleniu. Wiedział, kiedy wstać i mówić, a kiedy siedzieć i milczeć - wszystko dla dobra wspólnego zgodnie z maksymą: Quod bonum felix fastum fortunatumque sit - „Oby to było dla dobra, pomyślności i szczęśliwości nas wszystkich”. Bezspornie cieszył się wielkim autorytetem wśród pracowników, jak również studentów.

Profesor dawał nam wskazówki, jak mamy budować swój warsztat naukowy. Radził nam, że wokół problemu badawczego należy krążyć jako wilcy wokół daniela, kłaść się spać z myślą o swoim temacie i budzić się z myślą o nim. Zachęcał nas do trzymania na stoliku nocnym notesu i ołówka, aby być gotowym do zapisywania pomysłów i skojarzeń mogących pojawić się porą nocną. Jednocześnie podkreślał znaczenie odpoczynku i oderwania się od nurtującego nas problemu badawczego. Zachęcał do czytania lektur spoza dziedziny ekonometrii, wskazując, że one właśnie mogą być źródłem inspiracji dla umysłu przygotowanego, „rozgrzanego” wcześniejszym drążeniem tematu. 
Sam postępował zgodnie z tym, jak mówił. Profesor dzielił się z nami swoimi przemyśleniami i refleksjami związanymi z lekturami, które czytał. Wielokrotnie nawiązywał do artykułów przeczytanych w Jego ulubionym „Forum” przeglądzie prasy krajowej i światowej. Na ich bazie często inicjował dyskusję daleko odbiegającą od zagadnień ekonometrycznych czy ekonomicznych. Czytał książki z dziedziny filozofii, fizyki, medycyny czy psychologii. Interesował się muzyką klasyczną, operą. Budził nasz podziw i zdumiewał nas rozległością swoich zainteresowań.

Wprowadzał nas, jak dobry ojciec, w świat ekonometrii zabierając nas jako początkujących asystentów na konferencje naukowe. Bez wsparcia Profesora długo nie moglibyśmy jeździć na te konferencje. To dzięki Niemu poznaliśmy osobiście autorów, których wcześniej znaliśmy jedynie poprzez czytane książki. To dzięki Niemu dostapiliśmy zaszczytu siedzenia obok Wielkich Ekonometryków podczas uroczystych kolacji. Zabieranie nas przez Profesora na konferencje naukowe było nie tylko zaszczytem i nobilitacja, ale, ze względu na Jego autorytet naukowy, przede wszystkim najlepszą rekomendacją w świecie nauki.

To w Toruniu - na Wydziale Nauk Ekonomicznych i Zarządzania - Profesor zbudował zespół pracowników skupiony wokół koncepcji dynamicznego modelowania zgodnego - Jego autorstwa, do której nas z entuzjazmem przekonywał. Poszliśmy za Nim. Wielokrotnie doświadczaliśmy Jego wsparcia, opieki i inspiracji. Znajdował zawsze czas na rozmowy z nami, dzięki którym uczyliśmy się bycia ze sobą, odkrywania tego, co nas łączy. Działając słowami, Profesor dzielił się z nami swoją wiedza, a jednocześnie słuchał tego, co my mamy do powiedzenia. $\mathrm{W}$ ten sposób inspirował nas, trafnie wytyczał kierunki badań, zachęcał nas do podejmowania wysiłku, do studiowania problemów trudnych i oryginalnych. A gdy już usamodzielniliśmy się i zaczęliśmy „chodzić swoimi drogami naukowymi", innymi niż Jego, akceptował to i traktował jako naturalny i kolejny etap naszego rozwoju.

Profesor zawsze pamiętał o swoich nauczycielach: doc. Z. Chylińskim z Wyższej Szkoły Ekonomicznej w Szczecinie, obecnie Politechniki Szczecińskiej, prof. M. Ziomku z Wydziału Morskiego WSE w Sopocie, obecnie Uniwersytetu Gdańskiego, czy prof. Z. Pawłowskim z Wyższej Szkoły Ekonomicznej w Katowicach, obecnie Uniwersytetu Ekonomicznego. Wielokrotnie opowiadał nam o tych ludziach-pionierach, którzy popularyzowali nauczanie ekonometrii w Polsce. Szczególną atencją Profesor obdarzał prof. Pawłowskiego, jednego z największych ekonometryków polskich. Profesor wspominał w wielu opowieściach, jak prof. Pawłowski przyjeżdżał z Katowic do Szczecina na wykłady, i jak z kolei Profesor sam jeździł do Katowic na dyskusje naukowe $z$ prof. Pawłowskim. Profesor $w$ ten sposób przybliżał nam $z$ jednej strony świat nauki, a $\mathrm{z}$ drugiej strony kształtował $\mathrm{w}$ nas poczucie więzi mistrza $\mathrm{z}$ uczniem.

Profesor był dla nas przewodnikiem w świecie ekonometrii, a dzięki swojej uczciwości, życzliwości, zaangażowaniu i odwadze - również wzorem Człowieka, człowieka prawdziwie żyjącego. Wszystko, co robił Profesor mieści się 
w łacińskiej sentencji: Beate vivere est honeste vivere - „Szczęśliwe życie jest uczciwym życiem".

My, uczniowie Profesora, jesteśmy tym, kim jesteśmy dzięki temu, że mieliśmy to szczęście poznać Profesora, spotykać się z Nim, pracować, rozmawiać, dyskutować, śmiać się i bawić.

Za to wszystko wyrażamy Mu wdzięczność i dziękujemy. 
